\title{
REALIZATION OF KNOWLEDGE-ORIENTED INFORMATIONAL SYSTEM OF FOOD SAFETY
}

\author{
Y. Chaplinskyy \\ V.M. Glushkov Institute of Cybernetics of NAS of Ukraine
}

\begin{tabular}{l}
\multicolumn{1}{c}{ Key words: } \\
Food safety \\
Intelligence system \\
Food safety knowledge \\
Information system \\
Context \\
\hline \multicolumn{1}{c}{ Article history: } \\
Received 02.07.2018 \\
Received in revised form \\
25.07.2018 \\
Accepted 09.08.2018 \\
\hline
\end{tabular}

Corresponding author:

Y. Chaplinskyy

E-mail:

npnuht@ukr.net

\begin{abstract}
Trade globalization, liberalization of markets, modern food technologies, food safety requirements, economic development, changing social demands couse a continuous evolution of food systems all over the world. Dissemination of information and knowledge is the key task of any organization connected with generating and sharing knowledge, especially new kinds of unique (and valuable) content that are as usable and accessible. In this context, sharing of food safety knowledge and information is considered in the direction of a better quality of life for everyone in terms of economic, environmental and social issues. The basis for this is the modern information and communication technologies used to implement effective access to knowledge and information.

The purpose of given food safety information system is to share information to the user through the establishment of an electronic data system, including its structure of information and knowledge about food safety. The developed information system is a multi-user, interactive, user-friendly Web-based information system. The information and knowledge include various aspects such as a) knowledge and information about the production and processing industry; $b$ ) the food safety aspects including standards, laws, danger etc. The main interested people in the food safety system were identified as: food producers and processors, consumers, regulatory bodies, and educational organizations. Their information needs were devided in: commercial, educational, technical and general. Developed system give possibility to manage such information objects: news, market, companies, regulatory bodies, educational opportunities, grants, standards, laws, alerts, tips, FAQs etc.
\end{abstract}

DOI: $10.24263 / 2225-2924-2018-24-4-3$ 


\title{
ОДНА РЕАЛІЗАЦІЯ ЗНАННЕ-ОРІЕНТОВАНОÏ ІНФОРМАЦІЙНОÏ СИСТЕМИ 3 БЕЗПЕКИ ПРОДУКТІВ ХАРЧУВАННЯ
}

\author{
Ю.П. Чаплінський \\ Інститут кібернетики імені В.М. Глушкова НАН Украӥни
}

Глобалізачія торгівлі, лібералізачія ринків, сучасні харчові технології, вимоги до безпеки продуктів харчування, економічний розвиток, зміна соиіальних вимог викликають безперервну зміну в харчовій галузі в усьому світі. Почирення інформащії та знань є ключовим завданням будь-якої організаиії, яка пов'язана з виробленням і поширенням знань, особливо нових видів унікальних (та цінних) за змістом, які є корисними та доступними. В иьому контексті поширення інформації та знань з безпеки харчових продуктів розглядається в напрямку покращення якості життя для сучасних $i$ майбутніх поколінь, з точки зору економічних, екологічних та сочіальних питань. Основою для иього є сучасні інформаційні та комунікаційні технології, які використовуються для реалізачії ефективного доступу до відповідної інформації та знань.

Метою такої інформачійної системи з безпеки харчових продуктів $є$ розробка механізму поширення інформації та знань до кінцевих користувачів шляхом створення електронної системи, включаючи структуру інформації та знань, методів доступу та доставки, для питань, які пов'язані з безпекою харчових продуктів, для всіх зачікавлених учасників. Інформація та знання включають в себе різні аспекти: а) знання та інформацію з виробництва та переробки; б) аспекти безпеки харчових продуктів, включаючи стандарти, закони, небезпеки, навчальні матеріали $i$ т. д. Основними зацікавленими учасниками в системі безпеки харчових продуктів були визначені: виробники та переробники харчових продуктів, спожсиячі, регуляторні органи та освітні організації. Інформачійні потреби ичих зацікавлених сторін поділені на бізнесові, освітні, технологічні та загальні. Розроблена система надає можливість управляти різними інформаційними об' єктами, такими як новини, ринки, компанії, регуляторні органи, освітні можливості, гранти, стандарти, закони, попередження, поради, небезпеки, актуальні питання тощо.

Ключові слова: безпека продуктів харчування, інтелектуальна система, поширення знань, інформаційна система, контекст.

Постановка проблеми. Глобалізація торгівлі, лібералізація ринків, сучасні технології харчової промисловості, вимоги безпеки продуктів харчування в ланцюзі поставок продуктів харчування від ферми до столу, вимоги до харчові логістики, продажів продуктів харчування, зберігання продуктів харчування, вимоги щодо зниження ризиків використання продуктів харчування та виникнення хвороб харчового походження, необхідність підтримання довіри до безпеки харчових продуктів і продовольчої постачання, необхідність збільшення експортних можливостей харчової галузі є сучасними 
завданнями розвитку харчової галузі. Наявні підходи до реформування традиційної системи управління безпечністю харчовими продуктами не можуть вважатись достатньо ефективними, оскільки вони не визначають i адекватно не вирішують багатьох існуючих проблем, не можуть забезпечити ефективне реагування на швидкий розвиток та зміни, що привносять ймовірні ризики, не завжди враховують під час прийняття рішень найновіші наукові дані та наслідки для суспільства, не охоплюють та не розповсюджуються на весь харчовий ланцюг.

Слід також зазначити, що знання в складних предметних галузях, якою $є$ безпека продуктів харчування, дуже швидко змінюються або застарівають, 3'являються нові задачі та нові методи розв'язання. Тож для розв'язання різних прикладних задач необхідно мати розвинені засоби для управління, доставки та використання знань. Сучасні інформаційні технології можуть бути базою для реалізації ефективних систем безпеки продуктів харчування. Однією 3 цілей таких інформаційних технології є об'єднання накопичених знаннь із знаннями зацікавлених осіб і використання їх для розв'язання відповідних задач 3 безпеки продуктів харчування. При цьому в рамках такої інформаційної системи повинна забезпечуватися можливість отримувати релевантну, зрозумілу, реальну та доступну контекстну інформацію для розв'язання конкретних задач, орієнтованих на конкретні цілі, та $є$ специфічними для користувачів або груп користувачів або для розуміння певного процесу при прийнятті рішень.

3 огляду на вищевикладене створення інформаційної системи 3 безпеки продуктів харчування є актуальним завданням.

Аналіз останніх досліджень і публікацій. Сьогодні існують приклади використання інформаційних технологій при розв'язанні різних задач безпеки продуктів харчування, таких як управління мікробіологічними ризиками [1], ідентифікація критичних контрольних точок [2], використання сучасних технологій для ланцюга від ферми до столу [3; 4]. Але ці розробки не дають користувачам і групам користувачів отримувати інтегровану інформацію та знання щодо безпеки продуктів харчування.

Мета дослідження: розробка інформаційної системи, яка реалізує механізм поширення інформації та знань до кінцевих користувачів для питань, що пов’язані з безпекою продуктів харчування.

Викладення основних результатів дослідження. Проблема безпеки продуктів харчування - складна комплексна проблема, що вимагає численних зусиль для іï розв'язання. При цьому розв'язання цієї проблеми все більшою мірою залежить від використання ними інформації та знань як одних $з$ найцінніших ресурсів. Сьогодні це неможливо реалізувати без використання інформаційних технологій як основи для ефективного поширення й використання накопичених інформації та знань, досвіду фахівців і сучасних технологій управління в різних прикладних областях. Використання знаннє-орієнтованих технологій для створення, координації, передачі та інтеграції знань сьогодні розглядається як потужна конкурентна перевага на підприємстві, орієнтованому на постійні зміни ділових процесів. Так, щоб зробити корисними підприємству всю інформацію, що є у нього, досвід і кваліфікацію співробітників, підвищити якість рішень, що приймаються, i 
скоротити час реакції на змінні ринкові умови, потрібно створити інформаційне середовище для інтеграції данних і знань, що використовуються в різних ділових процесах.

Розроблена інформаційна система направлена на інтеграцію, накопичення та підтримку контенту щодо безпеки продуктів харчування, а також організацію доступу до нього різних учасників інформаційного процесу, що дає змогу: об'єднати різні джерела інформації в рамках єдиної системи; забезпечити постійний розвиток системи за рахунок поновлення знання та даних $\mathrm{i}$ безперервного накопичення нового досвіду; надавати релевантну інформацію конкретних запитів кожному з учасників інформаційного процесу відповідно до його знаннями, уподобаннями та потребами; забезпечувати розподілений доступ до контенту учасникам процесу.

Одним із головних завдань розробленої інформаційної системи є підтримка процесів поширення і використання інформації та знань щодо безпеки продуктів харчування. Під поширенням знань розуміється передача знань у потрібне місце, в потрібний час, 3 потрібною якістю. Мета таких процесів [5; 6] - об'єднати накопичені знання зі знаннями зацікавлених осіб і використовувати їх для розв'язання відповідних задач. Ці процеси 3 поширення знани та обміну інформацією займають центральне місце при навчанні, що, у свою чергу, має вирішальне значення для розвитку підприємства. Канали поширення й обміну інформацією є основою для забезпечення суспільного визнання рівня безпечності харчових продуктів і для гарантування надійності виробників та переробників продуктів харчування. Це передбачає обмін інформацією між організаціями, між замовниками та постачальниками, між організаціями та споживачами продуктів харчування, взаємодію із законодавчими й регуляторними органами та іншими організаціями.

Для реалізації інформаційної системи будемо використовувати модель реалізації поширення знань, що базується на розумінні того, що знання створюються за допомоги окремої людини або групи людей, і це знання залежить від існуючих знань, переконань та досвіду користувача. Це вимагає розгляду процесів, структур, ресурсів, навколишнього середовища, а також взаємодії між учасниками інформаційного процесу поширення та використання інформації та знань і відповідними засобами. Така модель базується на чотирьох вимірах (аспектах) використання знань (джерело, зміст, середовище та користувач (рис. 1).

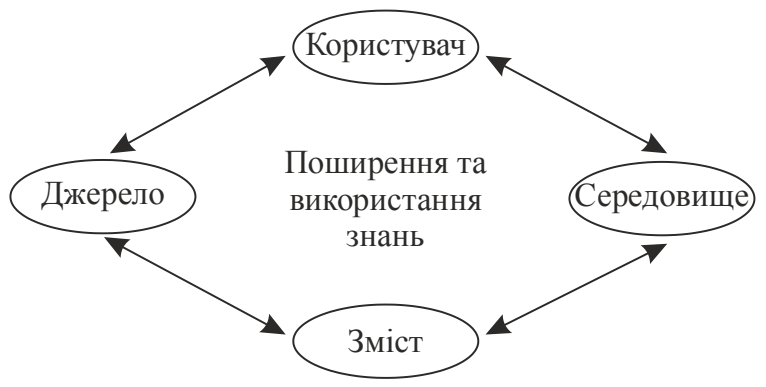

Рис. 1. Виміри процесу поширення знань 
Варто зазначити, що поширення інформації та знань $є$ набагато складнішим процесом, ніж просте надання доступу до відповідної інформації та знань. Цей процес вимагає врахування особливостей проблемної області, знань і контексту їх створення, потреб, контекстів, досвіду, переконань тощо цільової аудиторії та змісту, засобів, формату, мови тощо, які використовуються при поширенні та використанні цих цільових аудиторій.

Проведений аналіз разом з фахівцями Міжнародного інституту безпеки та якості продуктів харчування показав, що основними зацікавленими учасниками в системі безпеки продуктів харчування, що представлені на рис. 2, є: виробники та переробники продуктів харчування, споживачі продуктів харчування, регуляторні органи (законодавчі, регіональні тощо), науковці та навчальні заклади. Вони іє основними користувачами інформаційної системи.

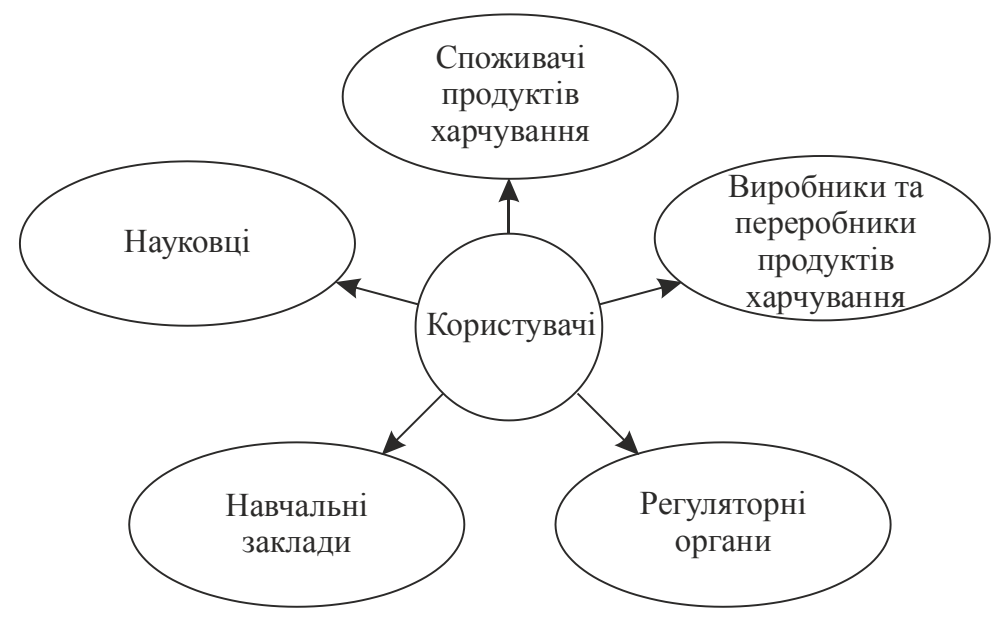

Рис. 2. Зацікавлені учасники інформаційної системи

При цьому інформаційні потреби цих зацікавлених сторін у рамках інформаційної системи поділяються на: комерційні (бізнесові), технологічні, освітні та загальні.

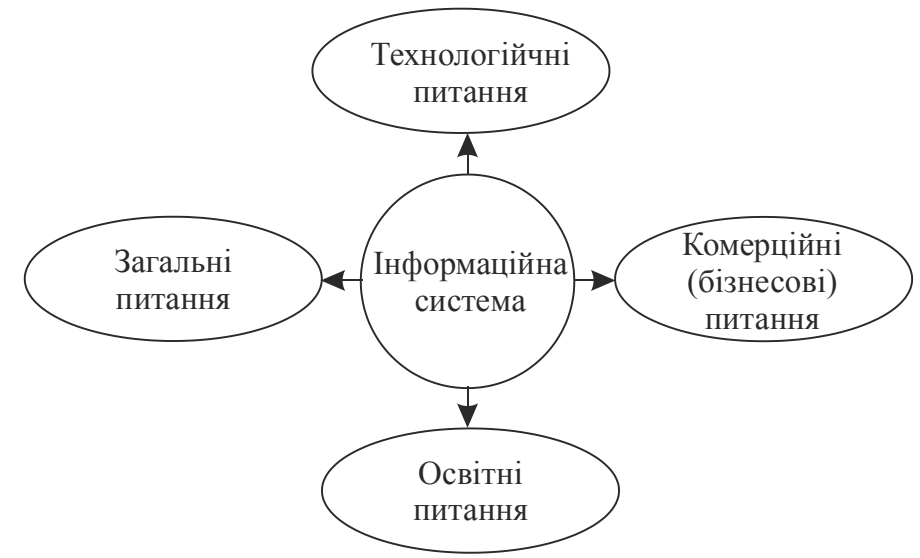

Рис. 3. Питання розгляду в інформаційній системі 
Так, наприклад, виробники та переробники продуктів харчування розглядаються в комерційному контексті через особливості ринків продуктів харчування, компанії, включаючи компанії, що працюють у сфері безпеки продуктів харчування, інформаційні ресурси щодо безпеки продуктів харчування, стандарти, програми та гранти, що стосуються безпеки продуктів харчування. Виробники та переробники продуктів харчування розглядаються в технологічному контексті через програми технічної допомоги, інформацію щодо виробничих процесів, які пов'язані з безпекою продуктів харчування, компанії провайдерів такої інформації. Споживачі продуктів харчування розглядаються в освітньому контексті через існуючі медіа програми та публікації, що стосуються безпеки продуктів харчування, курси та інші освітні можливості, поради щодо процесів 3 приготування їжи, існуючи небезпеки біологічної природи, хімічної природи та фізичної природи. Регуляторні органи розглядаються в загальному аспекті через новини (поточні спалахи хвороб, відкликання продуктів харчування, новин законодавства тощо), законодавство та існуючі стандарти як у країні, так за кордоном. Науковці та навчальні заклади розглядаються в освітньому аспекті через навчальні заходи для дітей, освітні можливості та компанії провайдерів навчальних заходів щодо безпеки продуктів харчування, організації з галузі безпеки продуктів харчування, з якими можна встановити партнерські відносини.

\begin{tabular}{|c|c|}
\hline Рівень представлення інформації \\
\hline \begin{tabular}{|c|}
\hline Представлення \\
результатів запитів
\end{tabular} & $\begin{array}{l}\text { Забезпечення навігації } \\
\text { за знаннями та даними }\end{array}$ \\
\hline \multicolumn{2}{|c|}{ Інтерфейс користувача } \\
\hline
\end{tabular}

Рівень обробки інформації

\begin{tabular}{|c|c|}
\hline \multicolumn{2}{|c|}{ Забезпечення обробки та потоків інформації } \\
\hline $\begin{array}{c}\text { Засоби пошуку } \\
\text { інформації }\end{array}$ & $\begin{array}{c}\text { Засоби побудови } \\
\text { контекстної інформації }\end{array}$ \\
\hline
\end{tabular}

Рівень зберігання та доступу до знань і даних

\begin{tabular}{|c|c|}
\hline \multicolumn{2}{|c|}{ Керування знаннями та даними } \\
\hline $\begin{array}{c}\text { Система управління } \\
\text { базами даних }\end{array}$ & $\begin{array}{c}\text { Семантичні технології } \\
\text { роботи зі знаннями }\end{array}$ \\
\hline
\end{tabular}

Рис. 4. Узагальнена архітектура інформаційної системи

Розроблена інформаційна система базується на інтегрованій моделі подання знань, що надає можливість розв'язання задачі - ефективного доступу до знань та інформаційних ресурсів через мережу Інтернет. Це дає змогу представляти в ній різнорідні знання та дані. На основі такої інформаційної 
моделі організовуються зручна навігація по знаннях та інформаційних ресурсах, що інтегровані в інформаційну систему, і змістовний пошук потрібної інформації щодо певних інформаційних об'єктів. Для організації ефективного доступу до ресурсів у контенті інформаційної системи представлена інформація за різними рівнями їх розгляду і деталізації та аспекти їх використання: в компаніях, споживачами, регуляторними органами, навчальними та науковими закладами, з якими пов'язаний їх розгляд, а також про різні їх змістовні характеристики. Ця інформація пов'язує ці ресурси 3 іншими даними та знаннями, які представлені в інформаційній системі, що дає змогу користувачу працювати з групами ресурсів, які стосуються його діяльності.

Інформаційна система базується на традиційній для інформаційних систем трирівневій архітектурі, що наведена рис. 4, та включає рівень представлення інформації, рівень обробки інформації і рівень зберігання та доступу до інформації (базовий рівень).

Розроблена інформаційна система складається із загальної частини (рис. 3) та адміністративної частини.

Загальна частина інформаційної системи забезпечує розміщення актуальної інформації, представлення інформації в зрозумілому для користувача вигляді, побудову ієрархії даних, при якій поряд з можливістю представлення узагальненої інформації існує можливість деталізації за рівнями та іншим параметрами.

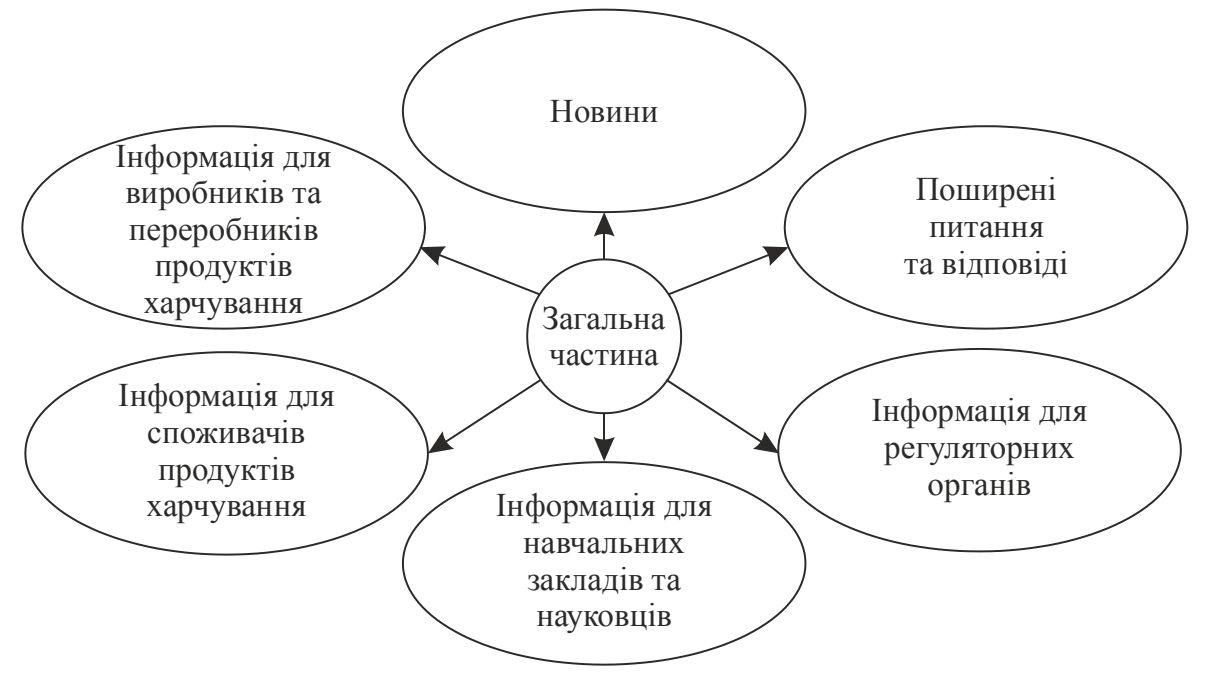

Рис. 5. Загальна частина інформаційної системи

Адміністративна частина надає можливість підтримки в актуальному вигляді контенту інформаційної системи.

Відповідно до прийнятої моделі вся інформація інформаційної системи представлена у вигляді множини інформаційних об'єктів та зв'язків між ними. Інформаційний об'єкт — це структурована сукупність даних, що представляє опис певного об'єкта обраної галузі знань або релевантного їй інформаційного ресурсу. Кожен інформаційний об'єкт відповідає контекстній 
області «об’єкт» та поняттю предметної області (є екземпляром цього поняття) та має задану структуру. Між конкретними інформаційними об'єктами можуть існувати зв'язки, семантика яких визначається відношеннями, що задані інформаційними об'єктами в рамках внутнішньобласної та міжобласної взаємодії.

Інформаційними об'єктами інформаційної системи є новини, сповіщення, компанії, освітні заходи та можливості щодо безпеки продуктів харчування, програми та гранти, небезпеки, закон, ринок, медіа-програми та публікації, регуляторні органи, поширені питання та відповіді, ресурси, стандарт, поради та користувачі.

Розглянемо опис деяких інформаційних об'єктів. Наприклад, інформаційний об'єкт «Новини» розглядається в розрізі новин компанії, що адмініструє цю інформаційну систему, новин про поточні спалахи хвороб, новин про відкликання продуктів харчування, новин законодавства та інших новин. Залежно від типу новин цей інформаційний об'єкт має відповідний опис, наприклад, новини про повернення продуктів харчування представляються таким чином: короткий опис новини; опис; забруднювач; місце; дата новин; опис новин; назва новини; джерело новини; заходи; продукти харчування, що пов'язані 3 новиною; люди, що пов'язані 3 новиною; причина; контактна людина; контактний емейл; контактний мобільний телефон; контактний телефон тощо.

Інформаційний об’єкт «Небезпеки» (рис. 6) описується так: небезпеки біологічної природи (назва небезпеки; коротка назва небезпеки; бактерія; фото бактерії; опис небезпеки; опис найбільш загальних симптомів; опис продуктів, що пов'язані з бактерією; опис інших профілактичних заходів; хвороби, що пов'язані з бактерією тощо); небезпеки хімічної природи (назва небезпеки; опис небезпеки; опис найбільш загальних симптомів; опис профілактичних заходів; хвороби, що пов'язані з небезпекою); небезпеки фізичної природи (назва небезпеки; коротка назва небезпеки; опис небезпеки; джерела небезпеки тощо).

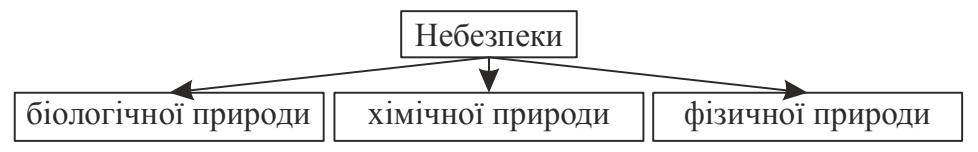

Рис. 6. Інформаційний об’єкт «Небезпеки»

Інформаційний об’єкт «Закон» описується таким чином: назва закону; коротка назва закону; тип закону; переваги закону; опис; регуляторний орган, що прийняв закон; вебсайт; що закон покриває; якої продукції стосується; кого стосується; закони, з якими пов’язаний даний закон; що закон покриває; рік прийняття; версія та рік внесення змін; посилання на закон в Інтернеті тощо.

Інформаційний об'єкт «Ринок» дає можливість представити особливості відповідного ринку продуктів харчування, що розгядається як національний ринок, ринок СНД, ринок ЄС, ринок США тощо.

Інформаційний об'єкт «Стандарти» описується таким чином: назва; коротка назва; тип; для якої аудиторії використовується; опис; компанія роз- 
робник стандарту; ринок застосування; Вебсайт та посилання на стандарт в Інтернеті; файл для загрузки тексту стандарту; переваги стандарту; що стандарт покриває (діяльність, продукція); з якими стандартами пов'язаний; хто проводить сертифікацію; сертифікаційна компанія; хто проводить інспекцію; інспектуча компанія; рік прийняття; версія та рік внесення змін тощо. Рівень розгляду стандартів: міжнародні, національні, регіональні, місцеві тощо.

Інформаційний об’єкт «Поради» описується так: назва, тип виробничого процесу, опис, ключові слова, джерело. Виробничі процеси, що стосуються порад, представлені на рис. 7.

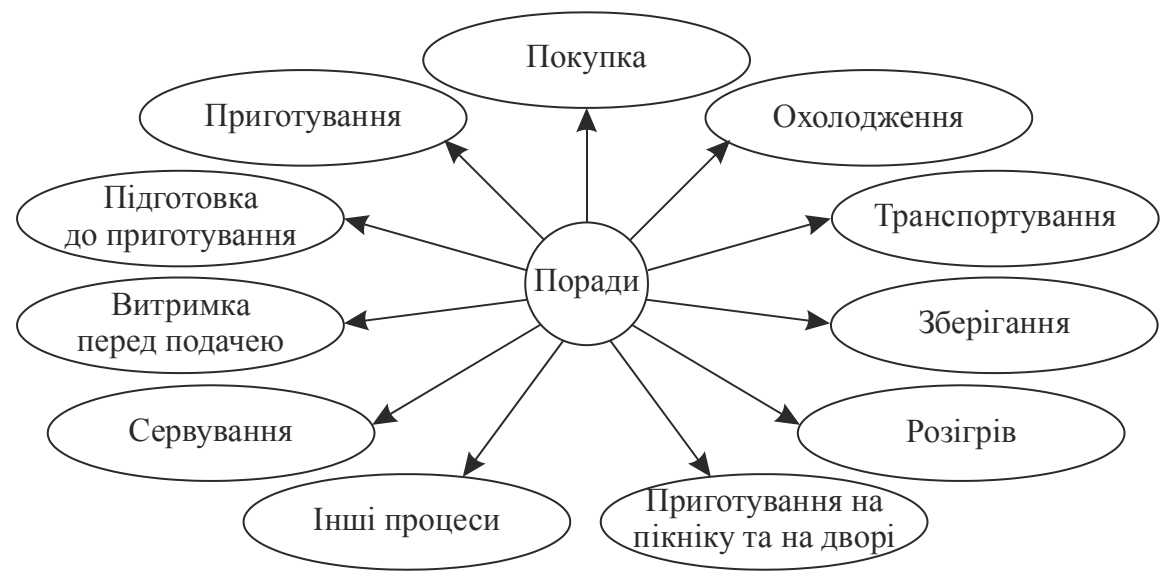

Рис. 7. Виробничі процеси, що стосуються інформаційного об' єкта «Поради»

Інформаційний об'єкт «Освітні заходи та можливості» описує освітні програми та освітні заходи, що пов'язані з безпекою продуктів харчування. Інформаційна система надає розлогу інформацію про освітній захід та компанію, що проводить його, дає змогу користувачу записатися на відповідний захід, що в подальшому забезпечить роздрук відповідного сертифіката, отриманого користувачем.

Інформаційний об’єкт «Ресурси» описує наявні Інтернет-ресурси щодо безпеки продуктів харчування. До таких ресурсів відносяться сайти організацій, компаній, портали і каталоги, а також окремі сторінки 3 матеріалами графічного, мультимедійного або текстового типу.

Реалізація інформаційної системи базується на використанні поняття контексту. Методологія управління контекстом орієнтована на формування моделі задачі користувача, що об'єднує в собі контекстно-залежну інформацію та знання, 3 подальшою інтерпретацією даного завдання як динамічної задачі задоволення обмежень, тобто представлення у вигляді певної Webсторінки. Визначення релевантної для певного користувача інформації, іiі інтеграція через контекст, отримання іiі від джерел інформації, привласнення значень, визначення правил візуалізації $є$ функціями технологій керування контекстом.

Контекст в інформаційній системі представляється контекстами трьох типів: абстрактним, конкретним і реалізації. За відправну точку роботи інформаційної 
системи взято вибір користувачем множини інформаційних об'єктів через меню. Після цього на підставі знайдених відповідностей формуються зрізи представлення даних, що містять релевантні атрибути вибору користувача, наприклад визначається шаблон візуалізації та відповідні необхідні інформаційні об'єкти та їх властивості. Такі зрізи інтегруються в загальний зріз. Таким чином буде сформовано абстрактний контекст вибору користувача. На підставі зв'язків 3 джерелами інформації, заздалегідь встановлених для властивостей інформаційних об'єктів, абстрактний контекст являє собою абстрактний опис представлення інформаційного об'єкта, побудованого на основі інтеграції знань проблемної області, релевантних для конкретного завдання. Конкретний контекст $\epsilon$ екземпляром абстрактного контексту з певною поточною інформацією, що визначається вибором користувача та знаходиться в базі даних. Контекст реалізації $є$ екземпляром конкретного контексту з визначиними середовищем візуалізації та відповідною компетентністю або роллю користувача.

Взаємодію з користувачем реалізує інтерфейс користувача, що представляється як сукупність програмних та апаратних засобів. Інтерфейс користувача базується на декоративній та активній складових. До декоративної складової належать елементи, що відповідають за естетичну привабливість Webсторінки. Активні елементи включають засоби управління, за допомогою яких користувач керує вмістом Web-сторінки. Такий інтерфейс реалізує об'єктноорієнтований інтерфейс, що використає модель взаємодії з користувачем, яка орієнтована на маніпулювання об'єктами предметної області. У рамках цієї моделі користувачеві надається можливість прямо взаємодіяти 3 кожним об'єктом та ініціювати виконання операцій, у процесі яких взаємодіють кілька об'єктів. Задача користувача формулюється як цілеспрямована зміна деякого об'єкта, що має внутрішню структуру, певний зміст та зовнішнє символьне або графічне подання. Взаємодії базуються на регламентованому обміні інформацією між користувачем та інформаційною системою, що здійснюється в реальному масштабі часу та спрямовані на спільне розв'язання конкретної задачі. Взаємодія складається 3 окремих процесів введення-виведення, які фізично забезпечують зв'язок користувача та інформаційною системою.

Графічні інтерфейси підтримують концепцію інтерактивної взаємодії із програмним забезпеченням, здійснюючи візуальний зворотній зв'язок 3 користувачем та можливість прямого маніпулювання об'єктами та інформацією на екрані. Крім того, інтерфейси даного типу підтримують концепцію зв'язаності програм, дають змогу переміщати між ними інформацію.

Змістовний доступ до систематизованих знань та інформаційних ресурсів з безпеки продуктів харчування, що представлені в інформаційній системі, організовується на основі розглянутої вище інформаційної моделі та здійснюється шляхом навігації по контенту інформаційної системи, а також через відповідні засоби змістовного пошуку в певних розділах інформаційної системи. Навігація $є$ процесом переходу від одних інформаційних об'єктів до інших за заданими між ними зв'язками, як правило, асоціативними. Використовуючи представлені зв'язки як елементи навігації, можна перейти до перегляду докладної інформації як за прямими зв'язками (про інформаційний об’єкт, про характеристики цього об'єкта), так і за зворотними. 
При цьому можливі переходи між окремими інформаційними об'єктами, перехід від поточного об'єкта до списку пов'язаних з ним об'єктів або вибір конкретного інформаційного об'єкта зі списку. При переході за конкретним зв'язком будь-якого інформаційного об'єкта ми можемо отримати досить великий список об'єктів (наприклад, стандартів). У зв’язку з цим був введений механізм фільтрації списків, який дає змогу, наприклад, відфільтрувати множину стандартів. Фільтрація - це спосіб вибірки підмножини об'єктів зі списку шляхом накладення на нього обмежень, тобто завдання фільтру. Фільтр є набором умов, які визначають допустимі значення атрибутів об'єкта і вимоги до існування зв'язків з певними інформаційними об'єктами.

При пошуці інформації користувачу надається можливість формулювання запиту в термінах предметної області. При цьому він повинен вибрати поняття, до якого відносяться певні інформаційні об'єкти, та визначити обмеження, яким повинні задовольняти атрибути обраного інформаційного об'єкта та його зв'язки з іншими інформаційними об'єктами. Пошукові запити задаються через спеціальний графічний інтерфейс.

При візуалізації контекстної інформації та виконання пошукових запитів враховується семантика інформаційних об'єктів, яка може бути реалізована через: опис об'єктів інформаційної системи; семантичний пошук; Формування списку об'єктів, що пов'язані з вихідним об'єктом; формування списку об'єктів, схожих на вихідний об'єкт.

При взаємодії з користувачем та для організації персоніфікованого представлення інформації використовується технологія профілювання. Завдання користувача інтерпретується як завдання задоволення обмежень, для його вирішення використовується технологія задоволення обмежень. Для налаштування інформаційної системи на конкретного користувача або групу користувачів до його складу включена інформаційна модель користувача. Зокрема, модель користувача містить роль, що визначає рівень доступу до даних, спосіб візуалізації сторінок, набір доступних функцій інформаційної системи.

Інформаційна система реалізується ASP.NET MVC Framework, що базується MVC патерн. Використання ASP.Net MVC надає змогу реалізувати взаємодію користувача з MVC додатком в рамках природного циклу: користувач здійснює дію, у відповідь на це додаток змінює свою модель даних і надає користувачеві оновлений вигляд. А потім цикл повторюється. А також ASP.Net MVC надає можливість об'єднувати декілька технологій. При цьому можна замінювати компоненти, такі як систему маршрутизації, засіб для перегляду тощо.

Для візуалізації інформації та отримання дій користувача використовується Јavascript-бібліотека jQuery. jQuery - бібліотека функцій JavaScript, спеціалізованих на взаємодії JavaScript та HTML. jQuery допомагає легко отримувати доступ до будь-яких елементів Web-сторінок, звертатися до атрибутів та вмісту елементів об'єктної моделі Web-сторінки і маніпулювати ними. Крім того, бібліотека jQuery надає зручні засоби для побудови користувацьких інтерфейсів з використанням технології Ајах.

Для роботи 3 відповідними інформаційнмим об'єктами використовується СУБД MS Sql Server та технологія роботи з даними Entity Framework. 
Для обміну даними між компонентами використовується формат JSON. $J S O N$ - це простий спосіб передачі структурованих даних, що базується на тексті. За допомогою JSON можлива передача як чисел та рядків, так i масивів, об'єктів, використовуючи при цьому текст. Цей формат дає змогу створювати та передавати складні структури даних.

Отже, розроблена Web-орієнтована інформаційна система є доступною через Інтернет інформаційною системою, що будується як система на принципах інженерії знань та забезпечує систематизацію та інтеграцію знань i інформаційних ресурсів з безпеки продуктів харчування, змістовний ефективний доступ до них і засобів їх інтелектуальної обробки. Крім того, система забезпечує пошук та навігацію по інформації та знаннях, підтримує широкий спектр засобів (середовищ) для професійного спілкування та обміну знаннями между фахівцямі, експертами, командами, групами. Інформаційна система надає можливість зацікавленим стронам значно скоротити час, необхідний для забезпечення доступу до необхідної інформації та ії аналізу, за рахунок акумуляції описів області знань і релевантних їй інформаційних ресурсів безпосередньо в контенті інформаційної системи. Завдяки реалізації інформаційної системи досягається функціональна інтеграція процесів консультування та прийняття рішень; міждисциплінарну інтеграцію знань та інформації 3 безпеки продуктів харчування; доступ до інформації, функцій та додатків, виходячи з компетенції та ролі користувача; надійна та маштабуєма архітектура; інтеграція ресурсів.

\section{Висновок}

Представлена інформаційна система реалізована в рамках науково-дослідної роботи «Розробка методів реалізації онтологокерованої підтримки прийняття рішень для безпеки продуктів харчування». Результати створення інформаційної системи можуть бути покладені в основу створення системи розповсюдження прикладних знань, що реалізують процеси підтримки інформування, консультування, прийняття рішень та навчання.

\section{Література}

1. McMeekin T.A. Information systems in food safety management / T.A. McMeekin, J. Baranyi, J. Bowman et al. // International Journal of Food Microbiology — 2006. — \# 112. P. $181-194$.

2. Лисииьн А.Б. Компьютерная методика формирования системы критических контрольных точек на примере технологического процесса производства вареных колбас./ А.Б. Лисицын, Ю.Г. Костенко, А.М Чернуха, И.И Протопопов // Хранение и переработка сельхозсырья. - 2007. - № 2 - С. $62-65$.

3. Xiaorong Zhao The Design of the Internet of Things Solution for Food Supply Chain / Zhao Xiaorong, Fan Honghui, Zhu Hongjin et al. // 5th International Conference on Education, Management, Information and Medicine (EMIM 2015). — 2015. - P. 314 - 318.

4. Doinea Mihai Internet of Things Based Systems for Food Safety Management / Mihai Doinea, Cătălin Boja, Lorena Batagan et al. // Informatica Economică, vol. 19, no. 1, 2015 - P. 87-97.

5. Nonaka I. The knowledge-creating company / I. Nonaka, H. Takeuchi - New York : Oxford University Press, 1995. - 284 p.

6. Johannessen $J$. Knowledge management and sustainable competitive advantages: The impact of dynamic contextual training. / J. Johannessen, B. Olsen // International Journal of Information Management, 23(4), 2003. - P. 277-289. 